\title{
Authoritarian Liberalism in Europe: A Common Critique of Neoliberalism and Ordoliberalism
}

\author{
Michael A Wilkinson \\ London School of Economics Law Department
}

\begin{abstract}
The differences between ordo and neoliberalism are many and varied. They include significant temporal and spatial differences, ascending in distinct places and periods of state transformation and capitalist development. They also include institutional and ideational differences: ordoliberalism is associated with rigid anti-majoritarian and pro-competitive rule-based institutions, in a primarily domestic context, neoliberalism with a looser set of political interventions directing class and geopolitical conflicts, domestically and imperially. This paper suggests, however, that within the constitutional dynamic of European integration and postwar reconstruction, ordo- and neo-liberalism represent a single movement: a conflation of political authoritarianism and economic liberalism in opposition to democracy and especially in opposition to democratic constituent power.
\end{abstract}

\section{Keywords}

Authoritarian Liberalism; Ordoliberalism; Neoliberalism; European Integration; Constitutional Imagination

\section{Introduction}

The differences between ordo- and neo-liberalism are many and varied. They include significant temporal and spatial differences, ascending in distinct periods of state transformation and capitalist development. They also include institutional and ideational differences: ordoliberalism is associated with rigid anti-majoritarian and pro-competitive rule-based institutions, in a primarily domestic context, neoliberalism with a looser, discretionary set of political interventions directing class and geopolitical struggles, domestically and imperially. I would like to suggest, however, that within the constitutional dynamic of European integration and postwar reconstruction, ordo- and neoliberalism represent a single movement: a conflation of political authoritarianism and economic liberalism in opposition to democracy and especially in opposition to democratic constituent power.

The dynamic of authoritarian liberalism is evident throughout the recent Eurocrisis, with politically authoritarian forms of governing emerging at national and supranational level in defense of programmes of economic liberalism, especially within the Eurozone (Wilkinson, 2013). Similar phenomena have been labelled 
'authoritarian neo-liberalism', grouping together recent critical conjunctures in Latin America and Southeast Asia, often under the auspices of the so-called 'Washington consensus' in international affairs (Bruff, 2014). In each of these contexts, principles associated with democracy and social rights are subsumed by a mode of governing that operates in accordance with capital accumulation, marketization and economic rationality.

The constitutional background to the Euro-crisis response is a mix of ordoliberal principles entrenched at the Treaty of Maastricht (price stability, fiscal discipline, avoidance of moral hazard), neoliberal political economic strategy pushed through conditionality programmes (austerity, privatization, deregulation) and ideological commitment to the European project ('if the Euro fails, Europe fails'). As a matter of legal and political form, ordoliberalism and neoliberalism are often in tension with each other, as ordoliberalism's rule-based commitments come up against neoliberal discretionary politics. But they are not in basic opposition, at least from the perspective of a constitutional theory that takes democracy seriously. On the contrary, a common denominator is the elision or repression of any democratic alternative to economic liberalism in general and austerity in particular. This is maintained in practice by a third factor: the material and ideological pressure to remain within the Euro-regime itself and the lack of any alternative political vision.

The Maastricht settlement is now coming to a head as the pressure placed on elected domestic governments (often self-imposed or imposed by other branches of the state or regional state-system) to remain within the single currency is increasingly matched by counter-pressure to leave in order to regain monetary authority. Italy is the latest Member State in which this stress is provoking constitutional crisis, with no apparent way out. And the basic dynamic affects creditor as well as debtor states, with anti-systemic parties and movements on the rise in Germany and France. The underlying tension, however, is not, as some argue, merely a temporary one linked to a period of economic emergency; on the contrary, it is hard-wired into the postwar constitutional settlement in Europe. The aim of the Euro-crisis measures is not to enable a future return to normal democratic politics, but to restore the pressure of the financial markets and the constraints imposed by them, reinstating by different means the same constraints (conditionality) now imposed through political coercion and institutional devices such as the European Stability Mechanism and the Outright Monetary Transactions of the ECB. The last decade of crisis response can be viewed as having effected, in practice, a conservative revolution: bypassing and circumventing normal parliamentary, democratic and legal accountability in order to conserve a liberal economic regime.

The deep constitution of this conjuncture can be explored by considering the longer pedigree of the confluence of political authoritarianism and economic liberalism (Wilkinson, 2017). German Social Democrat and constitutional theorist Hermann Heller coined the term 'authoritarian liberalism' in the interwar period (Heller, 2015), targeting with the label not only the centrist and conservative Cabinets of Chancellor Brüning that governed Germany before the Nazi party took power, but also the constitutional theorist who had advised them, Carl Schmitt 
(Bonefeld, 2017). Schmitt had recommended a strong state in order to defend the free market economy against the threat of democratic socialism and associated experiments of economic democracy, encapsulated in his address to the Langnamverein in 1932, 'strong state, free economy' (Cristi, 1998). This motto would be taken up and reformulated by the ordoliberals, who stressed not only the dangers of unfettered democracy but of unfettered capitalism and its tendency to self-destruct by leading to monopolies and cartels. The state needed to be strong to secure the legal and institutional conditions (the ordo) of the free market and disarm both democratic and capitalist threats to it.

The polemic between Heller and Schmitt took place in the crucible of late Weimar, as it was teetering on the brink of collapse. But with a longer historical arc in view, the combination of political authoritarianism and economic liberalism comes to appear less exceptional than normal. As Karl Polanyi argued, the pattern of authoritarian liberal response and reaction to economic crisis was far from unique to Weimar - right across the globe, states tried to maintain the political-economic demands of the Gold Standard, fiercely resisting social democratic movements through exceptional measures, until, eventually but unevenly, they abandoned Gold, and market liberalism, leading, for example, to Welfarism in Britain and the New Deal in the US (Polanyi, 2001 [1944]). According to Polanyi, the more fiercely countries resisted social democracy through authoritarian government in the name of economic liberalism and sound finances, the stronger and fiercer the eventual backlash (the 'double movement'). Authoritarian government hollowed out democracy, ultimately weakening its ability to respond to the Fascist threat when it arrived. It was, in other words, authoritarian liberalism that directly prepared the ground for Fascism.1

Polanyi's account opens up a broader point about the backdrop to the interwar conjuncture. The authoritarian state on which the defence of the interests and ideas of economic liberalism depended made its mark not only in the crisis response of the 1920's and 30's but in the initial forging of the market society across the nineteenth century. The market society was not spontaneous but planned and often coercively implemented using a strong, authoritarian state apparatus.

Taking a similar tack, the argument here is that authoritarian liberalism signifies not only the exception, the crisis response, but also the norm, the postwar European constitutional state and regional order. This is reconstituted from the beginning in an authoritarian vein in order to restore and maintain economic liberalism after its interwar collapse. The project of European integration plays a significant role in this restoration, beginning with the supranational institutions of the Paris and Rome Treaties. But it is a domestic as much as a regional reconfiguration.

This new brand of authoritarianism reflects the reaction of political elites (as well as large sections of the people themselves) to the fear of a democratic- and classconsciousness that was unleashed in the interwar period and that remained a threat to the stability of a liberal order. Although this postwar settlement has been captured by the label of 'restrained democracy', or even the inappositely named 
'militant democracy', these labels conceal a de-democratisation of the political process, with matters taken out of the hands of ordinary democratic politics in order to promote political and economic stability (Müller, 2011). Indeed, the West German case represents a de-politicisation (qua de-democratisation) not only of ordinary politics but also of constitutional politics with its entrenched Basic Law and conservative constitutional culture, closely guarded by a Constitutional Court. It is from this perspective that we can see the neoliberal state of the 1970's and the recent austerity state of the financial crisis to represent a deepening rather than a departure from the authoritarian liberal trajectory of postwar state transformation.2

The purpose of this contribution is thus to suggest that despite important differences between ordoliberalism and neoliberalism, regarding, for example, their temporal arcs, ideological-institutional supports and geopolitical orientations, there is a constitutionally significant common denominator. In short, what may appear a conjunctural turn to political authoritarianism in the exceptional moment of economic emergency is rather a reflection of a deeper systemic feature of the prevailing postwar liberal order in Europe. This order is now in crisis, struggling to maintain the 'extreme centrism' it depends on for political support.

As yet, there has been no rupture from this postwar order but there is increasingly an inflection, where authoritarian liberalism is mixed with aspects of authoritarian illiberalism, particularly with regard to issues of identity and immigration as right-wing nationalism returns. This is occurring within the European Union, most evidently in Central and Eastern Europe but also in the core, such as in Italy. Brexit may follow this inflection. But if it were to signify a rupture with the postwar order of authoritarian liberalism, it would be through a reclaiming of democratic sovereignty over the economy. It is, however, too early to tell where Brexit will lead.

\section{Militant Democracy, Restrained Democracy or Authoritarian Liberalism?}

The crisis of the constitutional state in late Weimar Germany was a feature not only of the political and economic turbulence associated with reparations, war guilt and the Versailles Treaty. It was also a feature of domestic class struggle, predominantly between a class-conscious and politically emancipated working class and an anti-democratic and embittered ruling class. This threatened the political economic order guaranteed in the 1919 Constitution, which promised to protect economic liberalism as well as the social state, posing a dilemma well understood by its architect, Hugo Preuss (2000). Above all, it was the antidemocratic stance of political and economic elites that seriously hindered the long-term prospects of the Weimar Republic (Kershaw, 1990). The reaction of the governing elites and industrialists of the early 1930's to the political and economic instability, rendered more acute by the depression, was a combination of authoritarianism and economic liberalism. This configuration was identified by Heller and Polanyi as crucial to the collapse of Weimar (Heller, 2015 [1932]; Polanyi, 2001 [1944]). In their analysis, it was the capitalist market system and its 
material inequalities that ultimately undermined democracy and laid the path to the Fascist takeover.

Yet the message taken by mainstream constitutional theory in response to the extraordinary double movement and breakdown of liberal democracy it entailed in Germany (and elsewhere) would be quite different from the one Heller and Polanyi had conveyed. It was not the threat that capitalist inequality posed to democracy that resonated in the liberal constitutional imagination, but the threat that democracy posed to liberalism. The underlying concern was that democracy in general and the democratic constituent power in particular would erode or overturn liberalism and the constitutional order that undergirded it. This concern came to prominence through the work of another constitutional theorist of the period, who had emigrated to the US, but became closely involved in post-war German reconstruction, Karl Loewenstein. Loewenstein, writing in 1935, thought that liberal democracy needed to be more 'militant' in the fight against Fascism (and, if to a lesser extent, also against Communism) (Loewenstein 1935, 1937). The structures of the Weimar republic should have been more flexible in order for it to defend itself, by suspending constitutional rights, banning political parties, and preventing the rise of extremist groups and associations. Lowenstein, describing the opportunism of the Fascist opponents of the constitution, urged liberal democracy to pre-empt them, to take the fight to its enemies, to 'fight fire with fire' (Loewenstein, 1937: 432). This echoed Carl Schmitt's own earlier call for robust defence of the Weimar constitution, by dictat and decree if necessary.

In the aftermath of World War II, mainstream political and constitutional theory thus became preoccupied with liberal constitutional defence, Loewenstein's warning apparently heeded. This narrow attention to constitutional form, however, elided the sociological examination of the power structures and social inequalities that undermined democracy in a capitalist state and state-system. The West German practice of entrenching strong constitutional guarantees to protect individual rights became increasingly influential and widespread (however misleading the conventional narrative of the dignified reaction to Nazism (Hailbronner, 2015). Constitutional lawyers, and those tasked with designing legal and political institutions, were dedicated to the justification of various institutional arrangements - whether domestic, international or supranational that would constrain majoritarianism, with the rationale (or pretext) of preventing democratic backsliding or avoiding democratic irrationality. Independent technocratic institutions such as constitutional courts, expert commissions, and central banks, became the norm, and were gradually engrained in the liberal constitutional imagination. European integration was an intrinsic part of this post-war settlement, representing the construction of a 'militant democracy writ large', a project generated by administrative and bureaucratic processes rather than democratic energies. The role of the European Court of Justice in conjunction with domestic courts in pushing forward integrationthrough-law would be central to the success of the project (Wilkinson, 2017).

Jan-Werner Müller, with the label of 'restrained democracy', offers a more accurate assessment of this set of phenomena than suggested by the inappositely named 'militant democracy' (Müller, 2011). Müller shows how it was liberalism 
and political moderation that was to be militantly advanced and protected, albeit in the name of democratic consolidation. The dominance of Christian Democratic parties and a widespread ethos of social Catholicism played a strong part in this resettlement. But to Müller's account must to be added a view of this constitutional architecture from the perspective of its political economy; militancy was driven by concerns to keep the wheels of economic liberalism revolving as much as it was to defend political liberalism, still less to promote strong democracy. Authoritarian liberalism is therefore a more appropriate label given both the means (various forms of de-democratisation) and the ends (economic liberalism and market building).

In constitutional enquiry, the focus was on the dangers of strong (unfettered) democracy, rather than, as Heller and Polanyi had warned, of unfettered capitalism and its tendency towards socio-economic inequality. The fragility of the Weimar constitution in the absence of constitutional review and even legal positivism's relativising of the question of legitimacy are blamed by constitutional theorists and legal philosophers for Weimar's collapse (Fuller, 1985; cf. Neumann, 1942). Capitalism passes under the constitutional radar. If, in practice, the excesses of capitalism were tempered in the post-war trentes glorieuses through the building of the welfare state and various forms of corporatism and social democracy, this did not capture the attention of constitutionalists. The seminal texts of liberal political and constitutional theory were preoccupied with resolving the 'counter-majoritarian dilemma' through various devices of justification for constraints on the democratic will, both institutionally (through strong constitutional review) and ideologically (as in the later Rawlsian idea of 'reasonableness' or Habermasian 'rational consensus') (Rawls, 1993; Habermas, 1995). Democracy, rather than presented as an emancipatory opportunity, or a material struggle for political equality, is disarmed as 'liberal democracy', or dismissed as likely to entail a 'tyranny of the majority'. Popular sovereignty as democratic constituent power - the originary power of the people to constitute anew - disappears, subsumed into written constitutional law, unamendable provisions, juristic institutions and the protection of constitutional rights.

Mainstream constitutional theory thus leads away from any critical engagement with political economy or of any problematisation of democratic capitalism as a constitutional question. European integration itself is initially given relatively little attention by constitutional scholars, neglected as a further stage of democratic capitalist development and state transformation. The creation of an internal market is seen tamely and benignly as designed only to ensure peace and prosperity after half of century of war and destruction. It is possible that post-war growth masked the political authoritarianism of the period. But it is apparent that however glorious the trentes gloriueses as a period of relative equalisation of material conditions, this was not a victory of democratic socialism but of a managed compromise of class interests, and not insignificantly, explained by the destruction effected by the Second World War (Piketty, 2013).

There was, however, a school of thought which did take - and had since the 1930's taken - seriously political economy as a constitutional question, placing economic freedom at the centre of its constitutional analysis. This was the school of 
ordoliberalism, as we will now explore in more detail. It is through understanding the ordoliberal constitutional imagnation that we can begin to unravel the authoritarian character of the postwar settlement.

\section{Ordoliberalism as Authoritarian Liberalism}

The post-war constitutional imagination in Europe was not characterised by any vision of a vibrant democratic state. It was encapsulated in the story of West German post-war constitutional development: 'we are (afraid of) the people' (Möllers, 2008). Reaction to this fear entailed a new vision not only of the governing function (in particular the technocratic functioning of government) but also of the governing relationship, the relation between state and society, and specifically of the restricted nature of the right to rule over the economy. In other words, this is a vision of de-democratisation both of the constituent and of the constituted powers, of sovereignty and of government. It lays out a new vision of political society, of the individual as a market participant rather than a political actor, a consumer rather than a citizen. It is, properly understood, authoritarian in character; but it is an authoritarianism based on a fear of freedom that has a class character as well as a socio-psychological dimension: it is not only that elites fear and distrust the people, but also that the people fear and distrust themselves (Fromm, 2001 [1941]).

As a constitutional vision, this was presaged in the work of the ordoliberals, whose founding meeting in Freiberg coincided with Schmitt's address to the Langnamsverein, 'strong state, sound economy'. Sharing Schmitt's vehement anticommunism, obsession with order, distrust of economic democracy, and belief in a strong state, they nevertheless presented unfettered capitalism, and not only democracy, as a challenge to the competition-based market society. Carl Joachim Friedrich identifies the ideological and constitutional significance of this 'new liberalism' as early as 1955, noting how it signals a fundamental re-ordering of the basic ideas underpinning constitutional theory (Friedrich, 1955). As Friedrich understood, and as Foucault would later explore in his lectures on neo-liberal governmentality in 1979, the decisive theoretical turn triggered by German ordoliberalism had been to replace constituent power (or popular sovereignty) with individual economic freedom - a freedom to participate in the market - as the legitimating device for the whole constitutional order (Foucault, 2008). This is not only a question of delegating power to technocratic agencies to avoid temporary democratic impulses; it is a basic elision or denial of political freedom and political agency.

The new economic constitutionalism of the ordoliberals reversed the original meaning of the economic constitution, which for Franz Neumann had meant democratic control of the economy (Neumann, 1987; Scheuermann, 1996). Instead, the constitution itself becomes sovereign, protecting the economy from democracy, through technocratic and legal means. For the ordoliberals, the new economic constitutionalism was required in order to achieve the complete abolition of class as well as national conflicts from the political domain (Bonn, 1982). It would be based on formal equality, individual economic rights and a 
competitive market economy. The class-conscious struggles of the inter-war period would be repressed in order to secure political and economic stability, threatened by the democratic forces that the inter-war period had unleashed. The new political theology of the post-war order would be fiscal prudence and economic efficiency, the model of the German 'economic miracle'. Democracy would be curtailed not (only) for fear of its violating civil or political rights but out of concern for its impact on the economy. The strong state and its constitutional and legal apparatus would protect the market economy, and disarm any democratic or capitalist threats to it.

Although it was far from straightforwardly applied (in practice softened by the Social Market economy and aspects of corporatism), this reconfiguration of the constitutional imagination would become ideologically ascendant, first in Germany and then elsewhere, not least through its influence on the process of European constitutionalisation (Slobodian, 2018; Cf Wigger, 2017). The selfunderstanding of constitutionalism in Europe would be increasingly conditioned by ideologies and interests that correspond to economic rationality and the logic of market competition, effecting a new differentiation of the political and economic realms by taking matters out of domestic democratic decision-making (Mestmäcker, 2007). In conjunction with principles developed by the European Court of Justice this would import a strong economically liberal bias into the project of European integration (Scharpf, 2010). It is a trend that would become more acute in time and of course extend far beyond the EU (Jayasuriya, 2001; Gill and Cutler, 2014).

At the Treaty of Maastricht, the differentiation between the political and the economic is taken to a new stage through the constitution of Economic and Monetary Union (EMU). EMU is based on the separation of supranational monetary policy from domestic fiscal authority and on the avoidance of moral hazard, prohibiting monetary financing as well as debt sharing. In this configuration, a Member State's ability to spend and repay its existing debts would be based on its own ability to raise resources, which - in the era of the 'debt state' (and not least due to tax arbitrage in a world and European market where capital moves relatively freely) - was increasingly undertaken through financial borrowing. The market was meant to ensure that interdependent states would retain sound finances, backed up institutionally by a Stability and Growth pact that was, however, seriously under-enforced, notably against France and Germany in its early phase, before the financial crisis (Menendez, 2013).

The new stage of integration represented by EMU must be understood in the broader context of neo-liberal globalisation of the 1980s, and the turn to financialisation of the economy. This incorporated a loosening of capital controls, with the free movement of capital effectively becoming a fundamental right within the EU (Menendez, 2013). With its commitment to a de-politicised monetary policy based exclusively on price stability and an independent but limited European Central Bank (ECB) with restricted monetary tools and without the guidance of any supranational economic policy capable of dealing with uneven development, socio-economic heterogeneity, or exogenous fiscal shocks, the 
Maastricht Treaty attempted to supra-nationalise ordoliberal principles designed for domestic implementation (Tuori and Tuori, 2012).

Maastricht would also signal an end to the functionalist logic that economic integration would prompt political integration, and that politicisation would then force elites to engage mass publics in European matters and precipitate a process of Euro-democratisation (Marks and Hooghe, 2009). On the contrary, it removed an important lever of power from the political pillars of the Member States, but without reconstructing it at the supranational political level or establishing any plans to do so. The new currency - a 'currency without a state' - would not only be democratically unaccountable; it would also lack the social and political bonds of community to sustain it, offering a symbol of the new era of 'economic Messianism' (Wilkinson, 2014). To adopt Wolfgang Streeck's heuristic (Streek, 2013), Maastricht seemed a decisive victory for capitalism over democracy, and just as commentators were proclaiming 'the end of history' with the collapse of the Soviet Union. Even supposedly critical theorists came to announce the impossibility of any alternative to capitalism and presented the European Union however flawed in its detail - as an unequivocally emancipatory project, a stepping stone to the world society. 3

The Maastricht project flows from the same premises of market-building, economic rationality and de-politicisation (qua de-democratisation) that characterised the deep reconstitution of postwar Europe. It signals an exaggeration of the separation of the political and the economic, now removing one of the key marks of sovereignty - the power of monetary authority - from the member states. It also, however, signals the point at which serious levels of popular discontent with the project would begin to emerge, ending the 'permissive consensus' of the foundational period. This could be seen in the rise of nationalist parties as well as various democratic shocks to the EU, in referenda from Denmark to Ireland, through to the failure of the Constitutional Treaty in 2005, rejected by the French and Dutch electorates but then repacked as the Lisbon Treaty, and now with the Brexit referendum.

\section{Euro-Crisis}

When the Euro-crisis hits, the Maastricht constitution struggles to hold, and the crisis response becomes subject to increasing social, political and legal contestation, from social movements in the margins, from positions of governmental power (as in the Greek case), and from strong domestic institutions such as the German Constitutional Court. Having lost faith in normal institutional routes, the apparatus of the state and European state-system increasingly resorts to cajoling and coercing, undermining even the moderate checks and balances of constitutional accountability in an attempt to maintain order (Wilkinson, 2015a).

The ordoliberal rules of the game established at Maastricht are in tension with the discretionary politics of neoliberal structural adjustment, as well as with the functional imperative to maintain the symbol of European integration, the single currency (e.g. the euro is 'irreversible', 'if the Euro fails, Europe fails'). In turn, all 
three come into conflict with the democratic and social movements against austerity, and in the case of Greece this was pushed (nearly) to the limit with the election of Syriza, an anti-austerity but pro-European government in January 2015. The circle is squared by permitting 'rescue programs', not as an act of democratic solidarity, but through a 'grey area' of Union law, and with strict conditionality attached (Menendez, 2013).

In this way, the narrative of moral hazard is switched from the risky behaviour of private creditors to the profligacy of public debtors - the greatest 'bait and switch' in history, as Mark Blyth calls it (2013). This permits a moralisation of the debt, and a (misleading) metaphor to take hold of the imagination, that of the frugal Swabian household, which saves before it spends. The ideology of ordoliberalism is maintained alongside the practice of neoliberall austerity. Fiscal indiscipline is avoided in theory, because states have to pursue the austerity programmes (the 'strict conditionality') that, it is claimed, would be demanded were they still subject to the discipline of the financial markets. States - and the banks they are indebted to - are rescued enough to avoid immediate default, but without the debt restructuring that would be necessary to escape future dependency (Jessop, 2017).

All of this suggests that the constitutional crises are not fundamentally about a formal conflict between emergency politics and the normal rules of the game. In practice, constitutional forms have been relatively easily bent or circumvented when necessary and dubious measures rubber-stamped by the European Court of Justice. They are rather surface indicators of a deeper crisis of the material constitution (Goldoni and Wilkinson, 2018).

Since democratic support for the EU is shallow and permissive, and increasingly fragile since Maastricht, the institutions and political elites that sustain it have to compensate in other ways, presenting those who contest the EU (and the austeriry regime associated with it) as irrational, unreasonable or un-European (Di Fabio, 2014). Euro-scepticism, misleadingly, is merely dismissed as illiberal, a feature of the new 'populism', a strategy only likely to reinforce democratic disconnect with the EU and bury the deeper causes of its malaise. Fear becomes the method of European integration in a more overt manner - not only a fear of democracy but of any serious questioning of the logic of further integration (Weiler, 2012). If the power of this method was apparent in the Greek crisis, with the ultimate capitulation of the Syriza government to the demands of the Troika despite the 'Oxi' vote, its limits may have been revealed through the recent Brexit referendum, testing for the first time, the capacity of a state to leave (Wilkinson, 2016).

To be sure, the Euro-crisis, and the response to it, suggests that the material order of democratic capitalism in the European state-system is nothing if not complex. The interests of capital are not always unified or aligned across the continent. They may diverge, marked by contests between capitals - London, Berlin, Paris, Athens, Rome and the national interests they represent (and of course misrepresent) - as much as between capitalism and democracy (Streeck, 20130. A study of authoritarian liberalism thus now needs to capture not only domestic de-democratisation, but the hegemonic relations between different capitals in a 
new 'German Europe', where every country is urged to imitate Germany's political economy despite the impossibility of such a demand (Thompson, 2013).

The Eurozone thus develops in a neo-colonial manner, along the lines of a coreperiphery relationship between 'creditor' and 'debtor' nations. Germany becomes the 'reluctant hegemon', and the Greek people are 'punished' for electing a leftwing government that dared to oppose the austerity agenda of the Troika and Euro-group (Habermas, 2015), only to capitulate eventually to the 'TINA' narrative ('There Is No Alternative' to neo-liberal structural reform). The domestic clash between capitalism and democracy is displaced by an imperial regime of integration; democracy pays the price.

\section{Conclusion}

Considered in the longue durée of the battle between economic liberalism and social democracy, Maastricht has been described as having put a decisive end to the European civil war between Right and Left that took place across the 'short twentieth century'. It signalled the triumph of economic liberalism over socialism. The victory of capitalism itself was even declared complete. As Etienne Balibar frames it, reflecting on the (re-) birth of the EU at the Treaty of Maastricht, what is extraordinary is the explicit and detailed setting of its liberal political-economic goals into rigid constitutional guarantees:

'The EU in its constitutive moment (Maastricht) was endowed with a quasiconstitution... where, for the first time in this part of the world... a principle of political economy deriving from a specific ideological discourse (namely neoliberal deregulation and unrestricted competition, believed to produce 'optimal allocation of resources' and spontaneously 'just' redistribution) was presented as the sovereign rule which all member states ought to implement in their national policies under close surveillance of the federal (or quasi-federal) organs of the Union...' (Balibar, 2014)

If the argument here is accepted, however, this battle, or at least its preliminary stages, may have already long been lost. The democratic implications of ordo- and neo-liberal political economy are underscored by the reconstitution of Europe right from the start of the post-war period. Once politics is reduced to a single political-economic logic, and the possibility of genuine renewal comes down to the possibility of exercising the constituent power, the autonomy of the political is reduced to a bare formality or the prospect of a revolutionary rupture. This resettlement occurs at the beginning of the post-war period, both through reconstitution of the European state and in significant part through the project of European integration. The differentiation of the political and the economic is cemented at Maastricht, continued into a further stage, with neoliberal financialisation representing a deepening rather than overturning of the post-war logic of integration.

To be sure, the post-war liberal constitutional imagination in Europe, though far from democratic, is more passively than actively authoritarian. It is technocratic, 
institutional, and juridical in terms of its constitutional form. In substance it is economically liberal, dedicated to expanding market integration, pursuing free trade and intensifying economic rationality. Politically, it is moderate, extreme only in the centrism it espouses and the technocratic and managerial ethos it embodies. Democracy is increasingly restrained if not yet extinguished.

This gradual hollowing out of democracy - central to both ordo and neoliberalism if pursued by different means - presages the more active authoritarianism to come. Although democracy had always been subdued in the post-war construct, since Maastricht, and especially since the Euro-crisis, it would be systematically over-ridden, and not only in response to parliaments but to popular referenda. 4 The 'Oxi' referendum in 2015 was the most explosive but far from unique expression of popular discontent that would be subsequently ignored or overturned. The full democratic cost has yet to be calculated.

If the ultimate capitulation of Greece suggests authoritarian liberalism in Europe may survive, developments elsewhere, as right-wing Eurosceptic parties surge in popularity (in Hungary, Poland, as well as in the core of Europe, in France, Germany and Italy) suggests that the authoritarian liberal suppression of the democratic voice may, as in the interwar period, tend not only to the victory of capitalism, but also to the resurgence of reactionary forms of authoritarian illiberalism. 5 Whether any reprisal of the inter-war breakdown of liberal democracy will more closely resemble tragedy or farce remains to be seen (Wilkinson, 2015b).

The current conjuncture has thrown the postwar settlement into doubt, if not yet into oblivion. It has been strongly contested, but there has been no definitive rupture, with the possible exception of Brexit. The UK is one of the few places in Europe to have avoided the 'Pasokification' (virtual annihilation) of the traditional centre left party, the UK Labour party under Jeremy Corbyn performing extraordinarily well in comparison to its sister parties on the Continent, with roughly $40 \%$ of the electorate, and becoming the biggest mass political party in Europe. There are of course particular features of the UK's constitutional landscape that explain this other than Brexit. But is it possible that the UK's departure from the status quo of EU membership, ironically given its advanced neoliberal trajectory, might lead not to a right-wing authoritarian illiberalism, as is occurring within the European Union, but towards a form of democratic socialism, as may only be feasible outside it?

\section{Notes}

1 According to to Polanyi, it was reaction to the 'deadlock of the market system' that precipitated the 'conjoint disintegration' of the political and economic system across the globe. Where liberals obstructed social and economic reforms that might involve planning, regulation or control, 'the victory of fascism was made 
practically unavoidable'. Rejecting purely local or historical explanations for the situation that gave birth to Fascism, 'in reality', Polanyi insists, the part it played was determined by one factor: 'the condition of the market system' (Polanyi, 2001 [1944]): 250-265).

2 The point is not to say that there is nothing new about neoliberalism, for example, as a regime of accumulation based on increasing financialisation of the economy and changing domestic and geo-political constellations of power. The point is rather that its newness does not consist in its authoritarian tendencies. On the significant features of neoliberalism, see e.g. Fine and Saad-Filho (2017). 3 Most notably Jürgen Habermas, declaring that since 1989, "it has become impossible to break out of the universe of capitalism; the only remaining option is to civilise and tame the capitalist dynamic from within" (Habermas, 2012: 106). This is the same Habermas who now declares Brexit the defeat of capitalism by populism, Die Zeit, 12 July 2016; http://www.zeit.de/kultur/2016-07/juergenhabermas-brexit-eu-crises-english, ( accessed 14 July, 2018).

4 The most conspicuous warning sign was surely the Dutch and French rejection of the EU Constitutional Treaty in 2005, which was followed by its repackaging in the Lisbon Treaty.

5 The turn to 'authoritarian populism' in Eastern Europe has been described as an inflection of, rather than rupture from, neoliberalism (Dale and Fabry, 2018).

\section{References}

Balibar E (2014) The Rise and Fall of the European Union: Temporalities and Teleologies. Constellations, Vol. 21, issue 2: 202.

Blyth M (2013) Austerity: The History of a Dangerous Idea. Oxford, Oxford University Press.

Bonefeld W (2017) Authoritarian Liberalism: From Schmitt via Ordoliberalism to the Euro. Critical Sociology, vol. 43, issue 4-5: 747.

Bonn EV (1982) Standard Texts on Social Market Economy: Two Centuries of Discussion (ed. Horst Friedrich Wunsche; tr Derek Rutter), Stuttgart, Gustav Fisher Verlag: ix.

Bruff I (2014) The rise of authoritarian neoliberalism. Rethinking Marxism, vol. 26.

Cristi R (1998) Carl Schmitt and Authoritarian Liberalism: Strong State, Free Economy, Cardiff, University of Wales Press, 1998.

Dale G and Fabry A (2018) Neoliberalism in Eastern Europe and the Former Soviet Union. In D. Cahill, M. Cooper, M. Konings and D. Pimrose eds., The Sage Handbook of Neoliberalism, London, Sage Publications.

Di Fabio U (2014) Karlsruhe Makes a Referral. German Law Journal, vol.15: 107. 
Fine B and Saad-Filho A (2017) Thirteen Things You Need to Know About Neoliberalism. Critical Sociology, vol. 43, issue 4-5: 685 - 706

Foucault M (2008) The Birth of Biopolitics — Lectures at the College de France 1978-1979, London, Palgrave MacMillan.

Friedrich CJ (1955) The Political Thought of Neoliberalism. American Political Science Review, vol. 49, issue 2: 509.

Fromm E (2001 [1941]) Fear of Freedom, Abingdon, Routledge (first published: Routledge \& Kegan Paul).

Fuller L (1985) Positivism and Fidelity to Law - A Reply to Professor Hart. Harvard Law Review, vol. 71: 630

Goldoni M and Wilkinson M (2018) The Material Constitution. Modern Law Review 81:4: 567 - 597

Habermas J (1995) Between Facts and Norms: Contributions to a Discourse Theory of Law and Democracy MIT Press.

Habermas J (2012) The Crisis of the European Union: A Response. Cambridge, Polity Press.

Habermas J (2015) 'Jürgen Habermas' Verdict on the EU/Greece Debt Deal -Full Transcript', interview by P Altermann The Guardian, 16 July 2015;

https://www.theguardian.com/commentisfree/2015/jul/16/jurgen-habermaseu-greece-debt-deal (accessed 14 July, 2018).

Hailbronner M (2015) Tradition and Transformations: The Rise of German Constitutionalism, Oxford, Oxford University Press.

Heller H (2015 [1932]) Authoritarian Liberalism. European Law Journal, Vol. 21, No. 3, 2015: 295.

Jessop B (2017) Finance-Dominated Accumulation and Enduring Austerity. In R Sturm, T Griebel and T Winkelmann (eds) Austerity: A Journey to an Unknown Territory. Discourses, Economics and Politics, Baden-Baden, Nomos Verlag: 29-49.

Kershaw I (1990) Weimar: Why did German Democracy Fail? Wiedenfeld and Nicholson, London.

Loewenstein K (1935) Autocracy versus Democracy in Contemporary Europe Part 1. The American Political Science Review, vol. 29, No.4: 571

Loewenstein K (1937) Militant Democracy and Fundamental Rights, Part I. The American Political Science Review, vol. 31, issue 3: 417 
Marks G and Hooghe L (2009) A Postfunctionalist Theory of European Integration: From Permissive Consensus to Constraining Dissensus. British Journal of Political Science, vol. 39, issue 1: 5.

Mestmäcker EJ, 'European Touchstones of Dominion and Law', The Ordo Yearbook of Economic and Social Order, 2007: 4.

Möllers C (2008) We are (Afraid of) the People: Constituent Power in German Constitutional Thought'. In M. Loughlin and N. Walker (eds) The Paradox of Constitutionalism, Oxford, Oxford University Press.

Müller J-W (2011) Contesting Democracy: Political Ideas in 20th Century Europe. New Haven, Yale University Press.

Müller JW (2011) Contesting Democracy: Political Ideas in 20th Century Europe, New Haven, Yale University Press.

Neumann F (1987) On the Preconditions and the Legal Concept of an Economic Constitution' in 0 Kirchheimer and F Neumann eds., Social Democracy and the Rule of Law (tr., L Tanner and K Tribe), London, Allen and Unwin, 1987).

Neumann F (2009 [1942]) Behemoth: The Structure and Practice of National Socialism 1933-1944, Chicago, Ivan R Dee 2009, first published: Oxford, Oxford University Press, 1942.

Piketty T (2014) Capital in the 21st Century. Harvard University Press.

Polanyi K (2001 [1944]) The Great Transformation: The Political and Economic Origins of Our Time, Boston, Beacon Press, 2001, first published: New York, Farran \& Rinchart, 1944.

Preuss H (200) The Significance of the Democratic Republic for the Idea of Social Justice. In A Jacobson and B Schlink eds., Weimar: A Jurisprudence of Crisis, Oakland, University of California Press.

Rawls J (1993) Political Liberalism, New York, Columbia University Press.

Scharpf F (2010) The Asymmetry of European Integration, or, why the EU cannot be a Social Market Economy, Socio-Economic Review, vol. 8: 211

Scheuerman W (1997) The Unholy Alliance of Carl Schmitt and Friedrich Hayek. Constellations, vol. 4, issue 2: 172.

Scheuermann W (1996) The Rule of Law Under Siege. Oakland, University of California Press.

Schmitt C (1998 [1932]) Strong State, Sound Economy. Reprinted in Cristi, Carl Schmitt and Authoritarian Liberalism: Strong State, Free Economy. 
Slobodian Q (2018) Globalists: The End of Empire and the Birth of Neoliberalism (Harvard University Press, 2018).

Streeck W (2013) Buying Time: The Delayed Crisis of Democratic Capitalism. New York City, Verso.

Thompson H (2013) Austerity as Ideology: The Bait and Switch of the Banking Crisis. Comparative European Politics, vol.11: 729.

Tuori K and Tuori K (2012) The Eurocrisis: A Constitutional Analysis. Cambridge, Cambridge University, Press.

Weiler JHH (2012) 'Editorial: Integration Through Fear' European Journal of International Law, vol.23

Wigger A 'Debunking the Myth of the Ordoliberal Influence on Postwar European Integration' in J Hien and C Joerges eds., Ordoliberalism, Law and the Rule of Economics, Oxford, Hart Publishing, 2017.

Wilkinson M (2013) The Spectre of Authoritarian Liberalism: Reflections on the Constitutional Crisis of the European Union. German Law Journal, vol. 14:527 560 .

Wilkinson M (2014) Economic Messianism and Constitutional Power in a German Europe: All Courts are Equal but Some Courts are More Equal Than Others. London, LSE Law, Society and Economy Working Papers 26/2014; http://papers.ssrn.com/sol3/papers.cfm?abstract_id=2522919 (accessed 14 July, 2018).

Wilkinson M (2015a) The Euro is Irreversible, or is it? On OMT, Austerity, and the Threat of 'Grexit". German Law Journal, vol.16: 1049.

Wilkinson M (2015b) Authoritarian Liberalism in the European Constitutional Imagination: Second Time as Farce? European Law Journal vol. 21, no.3: 313 339.

Wilkinson M (2016) The Brexit Referendum and the Crisis of Extreme Centrism. German Law Journal 17: 131 - 142.

Wilkinson M (2017) The Reconstitution of Postwar Europe: Liberal Excesses, Democratic Deficiencies. In M. Dowdle and M. Wilkinson eds., Constitutionalism Beyond Liberalism, Cambridge, Cambridge University Press: 38 - 79.

\section{For Correspondence:}

Michael Wilkinson, Law Department, London School of Economics and Political Science, Houghton Street, London WC2A 2AE, United Kingdom. Email: M.Wilkinson@lse.ac.uk 